\title{
Learner Experiences Related to Digital Education Schedules in Light of Empirical Data
}

\section{Beáta Orosz}

$\mathrm{PhD}$ School in Business and Management, Budapest University of Technology and Economics, Müegyetem rkp. 3, 1111 Budapest, Hungary

e-mail: orosz@metakepzes.hu

\begin{abstract}
In this work, I briefly introduce the theoretical foundations and main aspects of electronic learning, in order to explore and evaluate the instruction schemes implemented as a result of the digital transformation. I base my findings on the analysis of a questionnaire-based survey administered to a sample of students. My research aims at examining the efficiency of the implementation of digital instruction and the accompanying challenges at various levels of the education sphere. I was interested in students' Information and Communications Technology (ICT) preferences and usage habits and whether or not they possess vital digital competences in their own view. The digitally scheduled education programs introduced in response to the COVID-19 pandemic could not fully reach a level required for effective learning according to research findings. The responses revealed that several schools did not implement uniform systems, the educational materials were not suitable for independent learning, the given materials did not have a modular structure, the respective texts did not reflect a system oriented perspective, and it was proven that neither students nor teachers possessed digital literacy skills considered to be currently vital. The most important result of this statistical analysis entails that those students were more successful in the digital home-based education, who spent more time with Information and Communications Technology (ICT) use, regularly played with or used experience-oriented software and relied on smart devices for most of their studies.
\end{abstract}

Keywords: digital instruction; e-Learning; learner attitude

\section{Introduction}

The changes in the labor market and the related demands of an information based society have led to radical modifications, in educational spheres [1]. In countries of the developed world, strong causal correlations can be discerned between the quality of education and the rate of economic growth. Due to such developments the higher education sphere becomes increasingly competitive [2] and international competence testing scores provide quantified proof of the impact of 
improved educational systems on the economy. The profits gained from investments into good school systems, exceed the long-term costs related to lack of knowledge or information. In order for the rest of the world to catch up, the economic, qualification, vocation or trade structures, along with the main attributes of work-related tasks need to undergo a dynamic conversion, requiring the integration of ICT devices [3] and a substantial methodological renewal and shift of professional perspective [4]. Although educational policy makers and administrators expressed the need to integrate digital technology into general pedagogical practice in the 1990s, the issue has not lost its currency as the following few examples demonstrate. The 1996 White Paper [16] had already emphasized investment into human resources and regarded education and training as decisive factors behind economic development, while knowledge had to be adapted to the respective changes. In 2000, the European Union declared its intention to become the most dynamic and competitive knowledge-based economy in the world. In 2001-2002 the European Commission established a special work team to identify the key competences of lifelong learning [5]. In March 2017 the Rome Declaration emphasized the importance of high quality education, while the Council of Europe called for the adaptation of the training system according to the needs of the information-based society in October of the same year. In November 2017 the Gothenburg Summit issued a statement titled "The Strengthening of European identity by education and culture" declaring the right to high quality, inclusive, lifelong learning along with the Commission's expectations concerning the European training system. The Commission's educational summit organized in January 2018 emphasized the importance of inclusive, innovative, and valuebased education along with facilitating the maximization of the potential of digital devices via the improvement of digital competence and the quality of the education process. The European Digital Action Plan as one of the action plans of the European Education Area operative until 2025 was issued in 2018. The plan focuses on three key areas [6]: the promotion of access to ICT devices and more effective use of technology in order to eliminate educational inequality and to facilitate effective learning. Furthermore, it calls for the improvement of key competences required for lifelong learning [7]. The indispensable skills for digital citizenship include problem solving, familiarity with processing and creating digital content, effective handling of information, along with cooperation and communication skills. [18]

The third priority is improving the quality of education by integrating the results of various research and analysis efforts thereby making more accurate predictions possible. These concerns are integrated in the National Digital Education Strategy of Hungary as well. The COVID-19 epidemic required immediate response and the implementation of digital instruction schedules. Such changes not only impacted the educational structure, but had a profound influence on lifestyles and the rhythm of everyday life as well. It can be safely stated that digital competences have an unprecedented significance and importance especially for all actors in the education sphere including pedagogues, instructors, and learners. Digital 
transformation entailed the facilitation of offline and online learning via learning management systems. These LMSs, however, primarily facilitated asynchronous communication and learning in the form of downloading educational support materials and uploading, submitting the related homework. [19]

In my work, I briefly describe the theoretical background and main features of electronic learning, before discussing the forms of instruction introduced after the digital transformation via the analysis of the results of a questionnaire-based survey performed among the students. My research questions and the aim of my research was to explore the implementation of digital instruction at various levels of the school system along with enumerating the respective difficulties, ICT preferences, and using habits. I was also interested in the students' own evaluation of their digital competence level. I hope my findings will further advance research related to digital transformation and the given results and experiences contribute to the improvement of the efficiency and assure the success and problem-free nature of another digitally scheduled instruction effort, likely to be implemented in the near future.

\section{The Theoretical Foundations of e-Learning}

While one of the most important objectives within the education sphere is to impart knowledge and competences, enabling students to meet the actual requirements of the economy, the labour market and industry [8], the increasingly obsolete training structure of schools prevent the fulfilment of these expectations. Consequently, pedagogical researchers continuously explore options for the potential rearrangement of educational schedules in order to realize the abovementioned goals. Due to the increasing importance of digitalization the traditional educational environment is undergoing substantial changes. Thus, modern ICT devices capable of fulfilling system arrangement, information provision, and communication functions have become indispensable for schools and the education process in general. Since some parts of face to face instruction take place in a virtual space e-Learning becomes one of the potential solutions for the related educational problems. Therefore, familiarity with the basic aspects and theoretical foundations of e-Learning is vital to identifying and solving the challenges and difficulties accompanying the digital transformation process. [17]

There term "e-Learning" has been defined in a variety of ways. Ilma Kovács [9] offered a narrow interpretation by primarily viewing it as training systems connected to networks. A broader definition. implies any training scheme carried out with any ICT device. The definition forwarded by Forgó [10] presenting a narrow interpretation holds that "e-learning is a computer-based training format, which makes the teaching-learning process accessible to students via integrating the educational material, learning resources, tutor-learner communication, and 
interactive computerised instructional software into an uniform framework system based on effective and optimal knowledge transmission and learning methods." An example of a broader interpretation is provided by Bánkeszi and his associates who consider e-Learning or electronic knowledge acquisition an instruction perspective entailing ICT supported novel forms of learning and instruction processes reflecting formal, content-based and methodological renewal [11] [12]. E-learning has three main component forms: computer based learning, Internet or web-based learning, and distance learning.

\subsection{Computer-based Learning}

Computer-based learning or CBL is the latest and special form of Technology Based learning. The terms refer to the arrangement of the teaching and learning process around interactive computer use, which enables the learner to reach a certain level of proficiency via the use of symbols and without reading or writing. Originally, it was called Computer Assisted/Augmented/Aided Instruction (CAI) emphasizing programmed education as the respective previous methodological background. During Internet or web-based learning the network-connected computers function as the means of learning. Therefore, all benefits of networkbased learning including the access to unlimited amount of information, the option of electronic communication or the virtual exit from the learning environment are available for the user. This type of learning has been named Web Based Learning (WBL), Computer Supported Collaborative Learning (CSCL) and Distributed Learning (DL) and the given labels indicate only minuscule differences while facilitating both face to face and distance learning. Although distance learning provides a genuine alternative to traditional face to face learning, it demands wholly different skills and competences from teachers and learners alike. Students are expected to have strong motivation for academic progress along with possessing such key $21^{\text {st }}$ Century competences as computer literacy and technological fluency. The technological development and the expansion of the ICT devices gives rise to the need for high order skills including medium-specific learning strategies, cooperation and collaboration in the real and virtual space, critical processing and use of information available on the Internet, and the need and aptitudes for lifelong learning [13] [14] [20].

As a result of the integration of ICT devices into the instruction process and the formation of network-based connections, such learning environments are formed where the processing, modification, and forwarding of information take place with the help of digital technology. The main features of e-Learning functioning, in digital learning environments, includes a system oriented approach and effective systemisation facilitating the dissemination of appropriately arranged and modular educational material content accompanied with the necessary instructions and control programs [14]. The effective acquisition of such knowledge content and the maximisation of the potential of electronic learning including non-space and 
time dependent academic progress and the formation of one's own learning path can become possible only if the given contents are connected and integrated into a network [13] instead of digitally recording and storing traditional educational materials. The process also requires continuous updating of the given content and the control of the activities of the learner [15]. Consequently, e-Learning carried out in an electronic learning environment is not merely an alternative to traditional learning environments and schemes, but the next developmental stage in the learning process. Hence the introduction of digital work and instruction schedules raises the question whether the learners and digital natives compelled to partake in such schemes are capable to orient themselves in such environments along with processing the digital educational materials without appropriate preparation and advancement through the required developmental stages.

\section{Learner Experiences Related to Digital Transformation}

The need for digital transformation raises the issue of how students view this process and their respective beginning experiences. I started my survey two weeks after the full introduction of digital schedules and I used an on-line questionnaire. Utilizing social media sites and professional connections I relied on snowball sampling. Underage members of the sample were contacted exclusively through their teachers who forwarded the given questionnaire to the parents to secure their permission and support for completing the questionnaire anonymously. Respondents were fully informed about the respective research objectives and were assured of anonymity. The first part of the questionnaire focused on personal details, and background variables including sex, age, type of school, place of residence. The second segment concentrated on the use of digital devices with accurate explanation for the interpretation of the given ICT equipment. The survey utilized a five step Likert scale with 1 indicating total rejection and 5 standing for full acceptance.

Respondents had to reply to, or comment on 13 statements:

- I have basic ICT skills

- I am a confident user of ICT devices

- I like to use ICT devices for learning

- I regularly use ICT devices for learning

- I use more than one service/program simultaneously

- I can use my ICT devices in a function-oriented way for word processing, image processing, etc.

- I can share digital data with my students and peers on my own 
- I have already tried to use virtual reality based programs

- I prefer to learn with educational materials enhanced by pictures

- My preferred ICT device is the smart phone

- I like to participate in the digital lessons with my smart phone.

- I like digital lessons supported by presentations.

- I like to produce digital educational materials, texts or notes.

The next group of questions asked the respondents to estimate the total time they used their ICT devices per day, before the introduction of digital education and how much of that time was spent with actual learning. Furthermore, I was interested in the extent of change of the respective values at the time of the digital transformation and I also inquired whether the need had emerged for the acquisition or purchase of any ICT device in order to implement digital learning. The last set of questions were aimed at the potential use of game or experiencebased programs, or on-line surfaces for digital learning as dictated by current trends with special attention to the students' familiarity with the MaxWhere virtual reality-based presentation software.

I used descriptive statistical methods for the measurement and analysis of the quantifiable responses and due to the type of data I especially relied on such mathematical statistics methods of inquiry with a special focus on difference testing as the Mann-Whitney probe, the Kruskal-Wallis probe complemented with the Wilcoxon probe. I used the SPSS 23 software, for analysing the data. In this paper I am introducing only the more significant results below.

\subsection{Demographic Data}

Figures 1-3 show the distribution of the 842 member sample. According to Figure 1 , the sample contained boys approximately in $38 \%$, while girls made up the remaining $62 \%$.

Figure 2 demonstrates that the majority of the sample study in vocational training institution $(63.3 \%)$ and $12.4 \%$ attend secondary school.

Figure 3 suggests that most of the students live in Pest County and Budapest (40.9\%), while $18.6 \%$ reside in Somogy and $8.8 \%$ in Bács-Kiskun Counties. I aimed to identify the significant differences in the students' ICT use, competences, and attitudes based upon these background variables.

Having used the Mann-Whitney probe I found several significant differences in case of the sex-based compilation of the sample. According to the students' voluntary response significant differences can be discerned among girls regarding the following variables: possession of basic ICT skills, regular use of ICT devices for learning, simultaneous use of more than one service/program, effective goaloriented use of ICT devices, smart phone as preferred device used for learning, 
participation at digital lessons with smart phone, producing digital materials, texts or notes on their own (Table 1).

\section{Boys and girls}

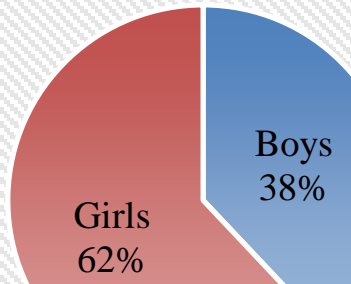

Figure 1

The distribution of the sample according to sex (author's own compilation)

Sex, male (boy), female (girl)

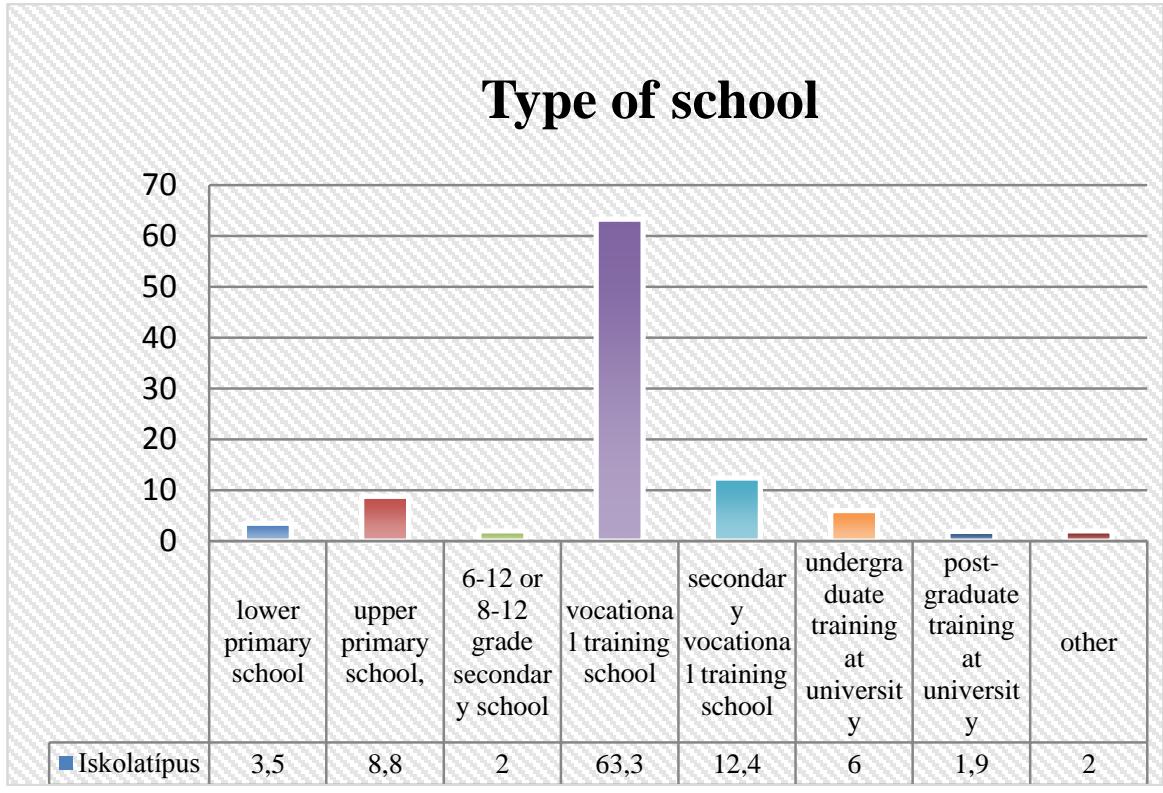

Figure 2

The distribution of the sample according to the type of school attended (author's own compilation) lower primary school, upper primary school, 6-12 or 8-12 grade secondary school, vocational training school, secondary vocational training school, undergraduate training at university, post-graduate training at university, other 


\section{Place of residence}

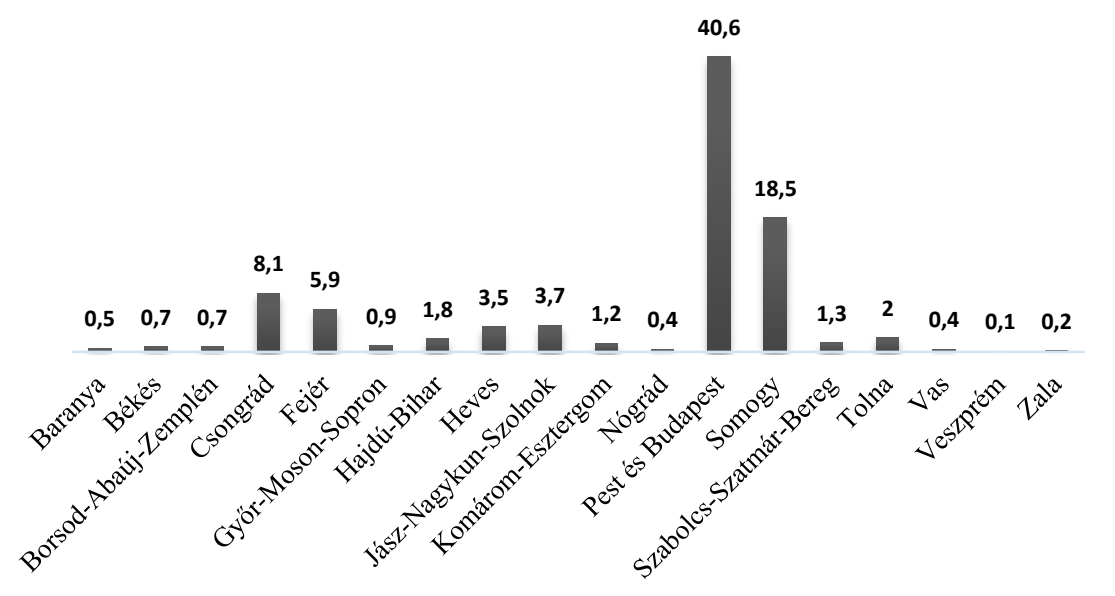

Figure 3

Percentage distribution of students according to place of residence (author's own compilation)

The given ranking point values are reinforced by the grouped medians, regularly indicating higher point values in case of girls.

Table 1

Statistical values of significant variables according to the sex of the respondents

\begin{tabular}{|c|c|c|c|c|c|}
\hline Variable & Sex & MR & $\mathbf{p}$ & $\mathbf{U}$ & $\begin{array}{c}\text { Grouped } \\
\text { Median }\end{array}$ \\
\hline \multirow{2}{*}{$\begin{array}{l}\text { I have basic ICT } \\
\text { skills. }\end{array}$} & Male & 390.762500 & \multirow[b]{2}{*}{0.002} & \multirow{2}{*}{73684.000000} & 4.04 \\
\hline & Female & 440.342912 & & & 4.27 \\
\hline \multirow{2}{*}{$\begin{array}{l}\text { I use my ICT } \\
\text { devices regularly } \\
\text { for learning }\end{array}$} & Male & 396.364063 & \multirow[b]{2}{*}{0.014} & \multirow[b]{2}{*}{75476.500000} & 3.83 \\
\hline & Female & 436.909004 & & & 4.03 \\
\hline \multirow{2}{*}{$\begin{array}{l}\text { I use more than one } \\
\text { service/program } \\
\text { simultaneously. }\end{array}$} & Male & 398.934375 & \multirow[b]{2}{*}{0.027} & \multirow[t]{2}{*}{76299.000000} & 3.98 \\
\hline & Female & 435.333333 & & & 4.14 \\
\hline \multirow{2}{*}{$\begin{array}{l}\text { I can use my ICT } \\
\text { devices in a } \\
\text { function-oriented } \\
\text { way for word } \\
\text { processing, image } \\
\text { processing, etc. }\end{array}$} & Male & 391.604688 & \multirow[b]{2}{*}{0.003} & \multirow[b]{2}{*}{73953.500000} & 4.00 \\
\hline & Female & 439.826628 & & & 4.24 \\
\hline \multirow{2}{*}{$\begin{array}{l}\text { My preferred ICT } \\
\text { device is the smart } \\
\text { phone. }\end{array}$} & Male & 389.956250 & \multirow[b]{2}{*}{0.002} & \multirow[b]{2}{*}{73426.000000} & 3.37 \\
\hline & Female & 440.837165 & & & 3.73 \\
\hline
\end{tabular}




\begin{tabular}{|c|c|c|c|c|c|}
\hline \multirow{2}{*}{$\begin{array}{l}\text { I like to participate } \\
\text { in the digital } \\
\text { lessons with my } \\
\text { smart phone. }\end{array}$} & Male & 397.231250 & \multirow[b]{2}{*}{0.020} & \multirow[b]{2}{*}{75754.000000} & 3.12 \\
\hline & Female & 436.377395 & & & 3.43 \\
\hline \multirow{2}{*}{$\begin{array}{l}\text { I like to produce } \\
\text { digital educational } \\
\text { materials, texts, or } \\
\text { notes. }\end{array}$} & Male & 388.303125 & \multirow[b]{2}{*}{0.001} & \multirow[b]{2}{*}{72897.000000} & 2.95 \\
\hline & Female & 441.850575 & & & 3.26 \\
\hline
\end{tabular}

Next, I relied on the Kruskal-Wallis test to ascertain the presence of a significant difference, according to the type of school the respondents attended. I included $\mathrm{PhD}$ students, those preparing for specialized pedagogical examinations, or participants in special training programs in the "Other" category. This category compared to other groups displayed substantially lower rank points and significant differences regarding preference for picture-supported educational materials. Likewise, this aspect does not have major significance for those enrolled in postgraduate Master programs either. (Table 2)

Table 2

Statistical values of significant variables in light of the schools attended by respondents

\begin{tabular}{|c|c|c|c|c|c|}
\hline Variable & School type & MR & $\mathbf{p}$ & $\mathbf{U}$ & $\begin{array}{c}\text { Grouped } \\
\text { Median }\end{array}$ \\
\hline \multirow{8}{*}{$\begin{array}{l}\text { I prefer to } \\
\text { learn with } \\
\text { educational } \\
\text { materials } \\
\text { enhanced by } \\
\text { pictures. }\end{array}$} & $\begin{array}{c}\text { Lower primary } \\
\text { school }\end{array}$ & 453.066667 & \multirow{8}{*}{0.020} & \multirow{8}{*}{16.681062} & 4.190476 \\
\hline & $\begin{array}{c}\text { Upper primary } \\
\text { school }\end{array}$ & 448.380000 & & & 4.166667 \\
\hline & $\begin{array}{l}\text { 6-8th grade } \\
\text { secondary } \\
\text { school }\end{array}$ & 462.411765 & & & 4.230769 \\
\hline & $\begin{array}{l}\text { Vocational } \\
\text { training } \\
\text { institution }\end{array}$ & 402.851504 & & & 3.895833 \\
\hline & $\begin{array}{l}\text { Secondary } \\
\text { school }\end{array}$ & 465.347619 & & & 4.226667 \\
\hline & $\begin{array}{l}\text { Undergraduate } \\
\text { at university }\end{array}$ & 493.637255 & & & 4.357143 \\
\hline & $\begin{array}{c}\text { Postgraduate at } \\
\text { university } \\
\text { Master }\end{array}$ & 378.133333 & & & 3.700000 \\
\hline & Other & 340.911765 & & & 3.600000 \\
\hline
\end{tabular}

The questionnaire also asked students to state the time they spent using ICT devices or on ICT-supported learning, before the digital transformation as compared to the respective values after the implementation of the digital instruction schedule. Since the normality test revealed that the respective data is not distributed in a normal manner, I relied on the self-control non-parameter equivalent of the one sample t-probe, the Wilcoxon probe. It was revealed that 
before the digital transformation students spent 3,726 hours on average with using their ICT devices and this value increased to 4,875 after the introduction of digital schedules, while the average time of ICT-supported learning increased from 2,461 to 3,666 . I determined the presence of significant increases, for both variables. (Table 3)

I examined the same variables with correlation calculation methods in order to ascertain the applicability of significant correlations and coincidence among the variables. It clearly proved the existence of a strong significant correlation and positive coincidence. The strongest correlation can be discerned in ICT use before and during digital transformation along with general and learning-oriented ICT use during the implementation of the digital schedule. Consequently, students who have already used their digital devices for a longer time even earlier could increase their usage time to a significant extent during the introduction of the digital instruction format. $(\mathrm{r}=0.562, \mathrm{p}<0.000)$, also in case of those respondents who spent more time in using their digital devices during digital instruction, a significantly higher portion was used for learning or study purposes. $(r=0.478$, $\mathrm{p}<0.000)$. The values of the correlation coefficients and that of the significance are shown in Table 4.

Table 3

Statistical values related to general purpose and learning-oriented ICT use prior to and during the introduction of digital transformation

\begin{tabular}{|c|c|c|c|c|c|}
\hline Variable & Average & MR+ & MR- & p & Z \\
\hline $\begin{array}{c}\text { How much } \\
\text { time do you } \\
\text { use your } \\
\text { digital devices } \\
\text { in general } \\
\text { (prior to the } \\
\text { introduction of } \\
\text { digital } \\
\text { schooling at } \\
\text { home) }\end{array}$ & 3.725653 & & & & \\
\hline $\begin{array}{c}\text { How much } \\
\text { time do you } \\
\text { use your ICT } \\
\text { devices in the } \\
\text { present time } \\
\text { on a daily } \\
\text { basis? }\end{array}$ & 4.875297 & 239.409856 & 195.221154 & $<0.000$ & -15.416744 \\
\hline $\begin{array}{c}\text { How much } \\
\text { time do you } \\
\text { use your } \\
\text { digital devices } \\
\text { for studying } \\
\text { (prior to the }\end{array}$ & 2.461401 & 267.114387 & 190.827381 & $<0.000$ & -14.807743 \\
\hline
\end{tabular}




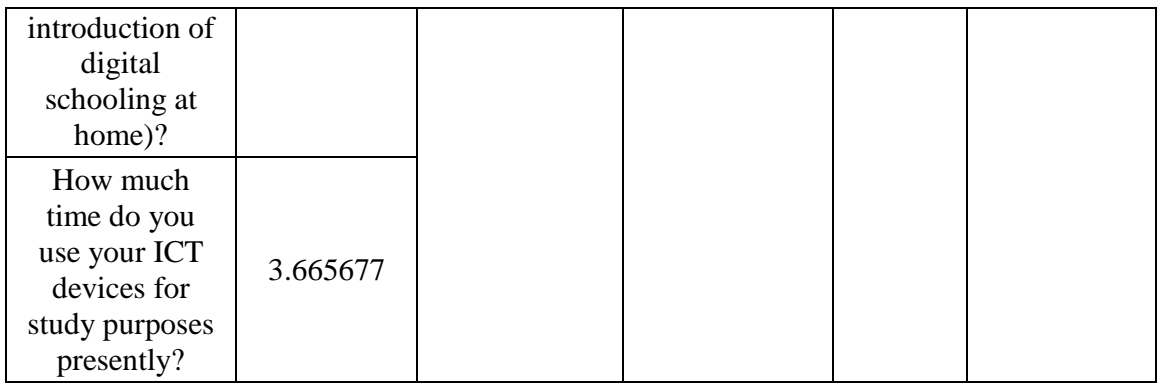

Table 4

Correlation calculation related to ICT use prior to and during digital transformation

\begin{tabular}{|c|c|c|c|c|c|}
\hline Variable & & $\begin{array}{l}\text { ICT use before } \\
\text { digital } \\
\text { transformation }\end{array}$ & $\begin{array}{c}\text { ICT use } \\
\text { during digital } \\
\text { transformatio } \\
\text { n }\end{array}$ & $\begin{array}{c}\text { ICT use for } \\
\text { learning prior } \\
\text { to digital } \\
\text { transformatio } \\
n\end{array}$ & $\begin{array}{c}\text { ICT use for } \\
\text { learning } \\
\text { during the } \\
\text { digital } \\
\text { transformatio } \\
n\end{array}$ \\
\hline \multirow{2}{*}{$\begin{array}{l}\text { ICT use } \\
\text { prior to } \\
\text { digital } \\
\text { transformati } \\
\text { on }\end{array}$} & $\mathrm{r}$ & 1 & 0.562 & 0.291 & 0.214 \\
\hline & $\mathrm{p}$ & & $<0.000$ & $<0.000$ & $<0.000$ \\
\hline \multirow{2}{*}{$\begin{array}{c}\text { ICT use } \\
\text { during } \\
\text { digital } \\
\text { transformati } \\
\text { on }\end{array}$} & $\mathrm{r}$ & 0.562 & 1 & 0.237 & 0.478 \\
\hline & $\mathrm{p}$ & $<0.000$ & & $<0.000$ & \\
\hline \multirow[b]{2}{*}{$\begin{array}{l}\text { ICT use for } \\
\text { learning } \\
\text { prior to } \\
\text { digital } \\
\text { transformati } \\
\text { on }\end{array}$} & $\mathrm{r}$ & 0.291 & 0.237 & 1 & 0.408 \\
\hline & $\mathrm{p}$ & $<0.000$ & $<0.000$ & & $<0.000$ \\
\hline \multirow[b]{2}{*}{$\begin{array}{l}\text { ICT use for } \\
\text { learning } \\
\text { during } \\
\text { digital } \\
\text { transformati } \\
\text { on }\end{array}$} & $\mathrm{r}$ & 0.214 & 0.478 & 0.408 & 1 \\
\hline & $\mathrm{p}$ & $<0.000$ & $<0.000$ & $<0.000$ & \\
\hline
\end{tabular}

Regarding place of residence as an independent variable I established significant digression in case of 8 dependent variables with the Kruskal-Wallis test. Table 5 shows the significance yielding variables and the counties with lowest and highest ranking points according to the given questions. It is important to note that the low number of the partial sample from Veszprém County provides an explanation for the emergence of significance. 
The responses reveal interesting digressions related to schools in different counties. One such example is that confident ICT use in Zala County coincides with the lower preference for using smart phones for learning, while in Veszprém County despite the professed preference for smart phones, due to the low level of ICT skills the functional use is limited. This result is likely to be substantiated by the higher number of simultaneously used programs.

Table 5

Statistical values of significant variables in light of the respondents' place of residence

\begin{tabular}{|c|c|c|c|c|c|}
\hline Variable & $\begin{array}{c}\text { Place of } \\
\text { residence }\end{array}$ & MR & $\mathbf{p}$ & $\mathbf{U}$ & $\begin{array}{c}\text { Grouped } \\
\text { Median }\end{array}$ \\
\hline \multirow{2}{*}{$\begin{array}{l}\text { I have basic ICT } \\
\text { skills }\end{array}$} & $\begin{array}{l}\text { Hajdú- } \\
\text { Bihar }\end{array}$ & 551.833333 & \multirow{2}{*}{0.002} & \multirow{2}{*}{39.641444} & 4.692308 \\
\hline & Veszprém & 53.500000 & & & 2.000000 \\
\hline \multirow{2}{*}{$\begin{array}{c}\text { I am a confident } \\
\text { user of ICT devices }\end{array}$} & Zala & 529.000000 & \multirow{2}{*}{0.048} & \multirow{2}{*}{29.058638} & 4.500000 \\
\hline & Vas & 303.833333 & & & 3.666667 \\
\hline \multirow{2}{*}{$\begin{array}{l}\text { I use more than one } \\
\text { service/program } \\
\text { simultaneously }\end{array}$} & Veszprém & 687.000000 & \multirow{2}{*}{0.001} & \multirow{2}{*}{43.650737} & 5.000000 \\
\hline & Nógrád & 200.000000 & & & 3.000000 \\
\hline \multirow{2}{*}{$\begin{array}{l}\text { I can share digital } \\
\text { data with my } \\
\text { students and peers } \\
\text { on my own. }\end{array}$} & $\begin{array}{l}\text { Szabolcs- } \\
\text { Szatmár- } \\
\text { Bereg } \\
\end{array}$ & 544.681818 & \multirow[t]{2}{*}{0.013} & \multirow[t]{2}{*}{34.000589} & 4.727273 \\
\hline & Veszprém & 125.500000 & & & 3.000000 \\
\hline \multirow{2}{*}{$\begin{array}{c}\text { I prefer to use } \\
\text { educational } \\
\text { materials enhanced } \\
\text { with pictures. }\end{array}$} & Baranya & 622.250000 & \multirow[b]{2}{*}{0.008} & \multirow[b]{2}{*}{35.634354} & 4.750000 \\
\hline & Veszprém & 196.000000 & & & 3.000000 \\
\hline \multirow{2}{*}{$\begin{array}{l}\text { I prefer to use the } \\
\text { smart phone as an } \\
\text { ICT device. }\end{array}$} & Veszprém & 714.000000 & \multirow[b]{2}{*}{0.018} & \multirow[b]{2}{*}{32.655929} & 5.000000 \\
\hline & Zala & 171.250000 & & & 2.000000 \\
\hline \multirow{2}{*}{$\begin{array}{l}\text { I like to participate } \\
\text { in digital lessons } \\
\text { with the smart } \\
\text { phone }\end{array}$} & Tolna & 504.941176 & \multirow[b]{2}{*}{0.006} & \multirow[b]{2}{*}{36.547617} & 3.888889 \\
\hline & Zala & 130.250000 & & & 1.500000 \\
\hline \multirow{2}{*}{$\begin{array}{l}\text { I like digital lessons } \\
\text { supported with } \\
\text { presentations }\end{array}$} & Baranya & 575.125000 & \multirow{2}{*}{0.003} & \multirow{2}{*}{38.341933} & 4.500000 \\
\hline & Veszprém & 212.500000 & & & 3.000000 \\
\hline
\end{tabular}

Next I explored whether the use of game or experience-based educational programs influence the ICT use and digital competence of students. The use or non-use of digital surfaces was considered as independent variable. The MannWhitney test showed that students learning with experience-based software tend to prefer image-based learning (Table 6).

Finally, I explored whether students were familiar with the MaxWhere program and any digression could be discerned compared to those not familiar with this virtual reality-based platform. 
Table 6

Statistical values of significant variable related to the use of experience-based programs

\begin{tabular}{|c|c|c|c|c|c|}
\hline Variable & $\begin{array}{c}\text { Do you use } \\
\text { game or } \\
\text { experience- } \\
\text { based } \\
\text { program/on- } \\
\text { line surface } \\
\text { for digital } \\
\text { learning? }\end{array}$ & MR & $\mathbf{p}$ & $\mathbf{U}$ & $\begin{array}{c}\text { Grouped } \\
\text { Median }\end{array}$ \\
\hline $\begin{array}{c}\text { I prefer } \\
\text { educational } \\
\text { materials } \\
\text { enhanced } \\
\text { with } \\
\text { pictures. }\end{array}$ & Yes & 455.3150412 & & & 4.191011 \\
\cline { 2 - 3 } & No & 407.542785 & 0.007 & 64989.500000 & 3.928125 \\
\hline
\end{tabular}

The respective criteria included ICT use, competence, and attitudes (Table 7). I found significant difference regarding two parameters. It appears obvious and it was substantiated by statistical probes that those members of the multitude under inquiry, who are familiar with the software, have already used other virtual reality-based program. The other difference referred to the participation on lessons with smart phones as those who are familiar with the program are less in favour of using smart phones on lessons.

Table 7

Statistical values of significant variables according to familiarity with the MaxWhere program

\begin{tabular}{|c|c|c|c|c|c|}
\hline Variable & $\begin{array}{c}\text { Have you } \\
\text { heard about } \\
\text { the } \\
\text { MaxWhere } \\
\text { virtual } \\
\text { reality- } \\
\text { based } \\
\text { presentation } \\
\text { program? }\end{array}$ & MR & $\mathbf{p}$ & $\mathbf{U}$ & GroupedMedian \\
\hline \multirow[b]{2}{*}{$\begin{array}{l}\text { I have } \\
\text { already } \\
\text { tried to } \\
\text { use virtual } \\
\text { reality- } \\
\text { based } \\
\text { programs. }\end{array}$} & Yes & 514.468750 & \multirow[b]{2}{*}{0.016} & \multirow[b]{2}{*}{9665.000000} & 3.555556 \\
\hline & No & 412.581250 & & & 2.576687 \\
\hline \multirow[b]{2}{*}{$\begin{array}{l}\text { I like to } \\
\text { participate } \\
\text { in digital } \\
\text { lessons } \\
\text { with my } \\
\text { smart } \\
\text { phone. }\end{array}$} & Yes & 308.921875 & \multirow[b]{2}{*}{0.008} & \multirow[b]{2}{*}{9357.500000} & 2.500000 \\
\hline & No & 420.803125 & & & 3.347222 \\
\hline
\end{tabular}




\section{Conclusions}

While professional research results on digital learning are widely available, scholars focused less on its reception by learners and the suitability of students for independent learning [25] [26] [27] [28] [29]. Consequently, I examined student attitudes toward digital instruction, the related experiences and the accompanying changes in ICT use. The main limit of the suryes was that the learners did not have any time to fill the form, and we couldn't reach enough students from all over the country. According to the results, the digitally scheduled education programs introduced in response to the COVID-19 pandemic, could not fully reach a level required for effective learning, according to research findings. The responses revealed several schools did not implement a uniform system, the educational materials were not suitable for independent learning, the given materials did not have a modular structure, the respective texts did not reflect a system oriented perspective, and it was proven that neither students nor teachers possessed digital literacy skills considered vital nowadays. While it is widely believed that the modern, digitally proficient student population is well-versed in working with digital devices, the survey answers provided herein, have shown deficiencies and uncertainties in accutal, functional use. One potential reason is the integration of web-based devices in face to face instruction at an increasing rate. Taking part in virtual reality-based learning environments, however, is a question of choice, thus several students have not received direct experiences regarding this option. The most important result of this statistical analysis shows that those students were more successful in digital home-based education, who spent more time with ICT use, regularly played with or used experience-oriented software and relied on smart devices in most of their studies. The pedagogues or educators of today face a major challenge, as they need to provide an example to their students, while teaching them problem solving and critical thinking skills and identifying the opportunities and dangers of the virtual learning environment, in order to enable them to become effective participants in electronic learning, if and when, a digitally scheduled instruction process is implemented again.

\section{References}

[1] López-Pérez, M. Victoria, López-Pérez M. Carmen, Rodríguez-Ariza Lázaro: Blended learning in higher education: Students' perceptions and their relation to outcomes. Computers \& Education, 2011, 56/3, pp. 818826

[2] Horváth Ildikó: The latest means and methods of digital instruction, THE MediaNet 2017, issue LXXII, pp. 6-9

[3] Ujbanyi T., et al.: ICT Based Interactive and Smart Technologies in Education - Teaching Difficulties. Proceedings of the $229^{\text {th }}$ International Conference on Education and E-learning (ICEEL), 2017, pp. 39-44 
[4] Bartha Z., Sáfrányné G. A.: Educational challenges in light of the technological revolution, Észak-Magyarországi Stratégiai Füzetek, 2018, $15 / 1,15-29$ p.

[5] Fredriksson, U. et al: Learn-ing to learn network meeting report. European Commission. Directorate JRC Joint Research Centre. Centre for Research on Lifelong Learning, 2006

[6] Farkas B. P.: The emergence of the European Digital Action Plan, Knowledge management group, 2018, Link: http://oktataskepzes.tka.hu/content/documents/KA3_Hirlevel/2018_aprilis/ Europa_Digitalis_Cselekvesi_Terv.pdf

[7] Gogh E., Kovari A.: Metacognition and Lifelong Learning: A survey of secondary school students, Proceedings of the $9^{\text {th }}$ IEEE International Conference on Cognitive Infocommunications, 2018, pp. 271-276

[8] Nemes J.: The connection between Industry 4.0 and public education, In: Kovács László - Varga Imre (ed.): Interdisciplinary approaches to economics (A gazdaság interdiszciplináris megközelítései), Savaria University Press, Szombathely, 2019, pp. 57-78

[9] Kovács I.: On electronic learning, Holnap Kiadó, Budapest, 2007

[10] Forgo S.: The concept of e-Learning, In: Hutter Ottó - Magyar Gábor Mlinarics József: E-Learning 2005 (e-learning kézikönyv), Müszaki Könyvkiadó, 2005

[11] Bánkeszi, K., Szepesi, J.: Electronic learning, or the main ideas of eLearning. Könyvtári figyelö, 2017, 63/4, 541-548

[12] Molnár B. (2019): Paradigm Shifts in the Development of Electronic Learning Environments I. Artificial Intelligence (Mesterséges Intelligencia) 1.1, pp. $41-52$

[13] Komenczi B.: Didactica electromagna? Virtual realities in e-Learning) Új Pedagógiai Szemle, 2004/11, Link: https://epa.oszk.hu/00000/00035/ 00086/2004-11-ta-Komenczi-Didaktika.html

[14] Komenczi B.: e-Learning from the student's perspective, In: Az e-learning szerepe a felsőoktatásban és képzésben, Harangi L.-Kellner G. Magyar Pedagógiai Társaság, Budapest, Magyar Pedagógiai Társaság, 2003

[15] Szimkovics T.: Theoretical and practical aspects of on-line course construction in teacher training, 2016

[16] White paper on education and training. Toward the cognitive society with teaching and learning (1996) Munkaügyi Minisztérium, Budapest, Comission of the European Communities, Brüsszel

[17] Kővári A. (2017) Project learning supported by cost-effective IT tools. HERA Yearbook 2016, 2017, pp. 273-284 
[18] Recommendations of the European Parliament and the Council of Europe on key competences required for lifelong learning (2006)

[19] Buda A.: Az Innovation options and beginning experiences of digital transformation) In: Kozma, Tamás; Juhász, Erika; Tóth, Péter (ed.) Tanulás és innováció a digitális korban, előadás, poszter és absztrakt, Debrecen, Magyarország: Magyar Nevelés- és Oktatáskutatók Egyesülete (HERA), 2020

[20] Komenczi, B.: Electronic learning environments, 2009, Link: http://publikacio.uni-eszterhazy.hu/3630/1/ETK.pdf

[21] Katona J., Ujbanyi T., Kovari A.: Investigation of the Correspondence between Problems Solving Based on Cognitive Psychology Tests and Programming Course Results, International Journal of Emerging Technologies in Learning, Vol. 10, No. 3, 2015, pp. 62-65

[22] Molnár Gy.: New challenges in the pedagogue career plan with special attention to digital literacy. In: Torgyik Judit (szerk.): Sokszínü pedagógiai kultúra. Nové Zámky, Szlovákia: International Research Institute, 2014, pp. 365-373

[23] Orosz B., Molnar Gy.: The impact of digitalization at various sites and levels of education facilitating the shaping of methodological culture) In: Fodorné, Tóth Krisztina; Németh, Balázs (szerk.) Felsőoktatási innovációk a tanulás korában: a digitalizáció, képességfejlesztés és a hálózatosodás kihívásai - tanulmánykötet. Pécs, Magyarország: MELLearN Felsőoktatási Hálózat az életen át tartó tanulásért Egyesület, 2019, pp. 80-93

[24] Molnár Gy.: Formal and informal web-based learning environments and the role of their inherent potential, In: Ollé, János (ed.) V. Oktatás-Informatikai Konferencia: tanulmánykötet. Budapest, Magyarország: ELTE PPK Neveléstudományi Intézet, 2013, pp. 196-201

[25] König, J., Jäger-Biela, D. J., \& Glutsch, N.: Adapting to online teaching during COVID-19 school closure: Teacher education and teacher competence effects among early career teachers in Germany. European Journal of Teacher Education, 2020, pp. 1-15

[26] Ratten, V.: Coronavirus (Covid-19) and the entrepreneurship education community. Journal of Enterprising Communities: People and Places in the Global Economy, 2020

[27] Iivari, N., Sharma, S., \& Ventä-Olkkonen, L.: Digital transformation of everyday life-How COVID-19 pandemic transformed the basic education of the young generation and why information management research should care?. International Journal of Information Management, 2020, 55, 102183

[28] Williamson, B., Eynon, R., \& Potter, J.: Pandemic politics, pedagogies and practices: digital technologies and distance education during the coronavirus emergency, 2020 
[29] Ferdig, R. E., Baumgartner, E., Hartshorne, R., Kaplan-Rakowski, R., \& Mouza, C. (2020) Teaching, technology, and teacher education during the covid-19 pandemic: Stories from the field. Waynesville, NC, USA: Association for the Advancement of Computing in Education (AACE), 2020 